\title{
QUEEN'S
UNIVERSITY
BELFAST
}

\section{An overview of acute gastrointestinal side effects of systemic anti- cancer therapy and their management}

Smith, P., Lavery, A., \& Turkington, R. C. (2020). An overview of acute gastrointestinal side effects of systemic anti-cancer therapy and their management. Best Practice and Research: Clinical Gastroenterology, [101691]. https://doi.org/10.1016/j.bpg.2020.101691

Published in:

Best Practice and Research: Clinical Gastroenterology

Document Version:

Peer reviewed version

Queen's University Belfast - Research Portal:

Link to publication record in Queen's University Belfast Research Portal

Publisher rights

Copyright 2020 Elsevier.

This manuscript is distributed under a Creative Commons Attribution-NonCommercial-NoDerivs License

(https://creativecommons.org/licenses/by-nc-nd/4.0/), which permits distribution and reproduction for non-commercial purposes, provided the author and source are cited.

\section{General rights}

Copyright for the publications made accessible via the Queen's University Belfast Research Portal is retained by the author(s) and / or other copyright owners and it is a condition of accessing these publications that users recognise and abide by the legal requirements associated with these rights.

Take down policy

The Research Portal is Queen's institutional repository that provides access to Queen's research output. Every effort has been made to ensure that content in the Research Portal does not infringe any person's rights, or applicable UK laws. If you discover content in the Research Portal that you believe breaches copyright or violates any law, please contact openaccess@qub.ac.uk. 


\section{Review}

An overview of acute gastrointestinal side effects of systemic anti-cancer therapy and their management

Padraic Smith ${ }^{1}$ MB BCh BAO BA MSc MRCP, Anita Lavery ${ }^{2}$ MB BCh BAO BSc MRCP and Richard C Turkington $^{2 *}$ PhD MB BCh BAO BSc MRCP

${ }^{1}$ Northern Ireland Cancer Centre, Belfast, United Kingdom

${ }^{2}$ Patrick G Johnston Centre for Cancer Research, Queen's University Belfast, Belfast, United Kingdom

*Corresponding author:

Dr Richard C Turkington

Patrick G Johnston Centre for Cancer Research

Queen's University Belfast, 97 Lisburn Road, Belfast, BT9 7AE, Northern Ireland, United Kingdom

Tel: +44 (0)289097 2756

Fax: $+44(0) 2890972776$

Email: r.turkington@qub.ac.uk

Co-author email: padraic.smith@belfasttrust.hscni.net ; anita.lavery@qub.ac.uk

Abstract Word Count: 124

Article Word Count: 7489 including references and tables

Number of Figures: 2; Number of Tables: 8; Number of Supplementary Tables: 2

\section{Authors' contribution}

P.S., A.L. and R.T. drafted the manuscript. All authors read and approved the final manuscript. 


\begin{abstract}
Treatment-related acute gastrointestinal toxicities are a common and often debilitating hurdle encountered in the treatment of cancer patients. While the introduction of targeted therapies such as tyrosine kinase inhibitors has led to improvements in survival outcomes, their use has also been complicated by a high frequency of clinically important adverse effects. Gastrointestinal toxicities such as nausea, vomiting, diarrhoea and hepatotoxicity represent potentially serious adverse events that may necessitate dose reductions, treatment interruptions and cessation of treatment. An improved knowledge of the incidence, pathophysiology, management and prophylaxis of these toxicities is crucial in order to reduce patient morbidity and mortality. In this review, we discuss the main gastrointestinal toxicities associated with chemotherapy and targeted therapies in oncology, outlining their incidence, pathophysiology and expert management guidelines.
\end{abstract}

Keywords: chemotherapy, targeted therapy, gastrointestinal, toxicity 


\section{Introduction}

Many cancer patients receive either curative or palliative systemic anti-cancer treatment (SACT) throughout their illness. 28\% of cancer patients in England receive chemotherapy but this rises to $46.1 \%$ and $38.7 \%$ for stage 3 and 4 cases respectively (1). Gastrointestinal (GI) side-effects of SACT such as diarrhoea, nausea, vomiting and hepatotoxicity can cause treatment delays or discontinuation, dose adjustments and significant morbidity and mortality $(2,3)$. Here we discuss the main acute gastrointestinal toxicities associated with chemotherapy and targeted therapies used in oncology. We first provide a summary of the relevant anticancer agents associated with each toxicity followed by an overview of clinical and pharmacological management.

\section{Diarrhoea}

Diarrhoea is a well-recognised adverse effect of systemic anticancer therapy (SACT), defined as the frequent passage of loose stools associated with urgency, or a more frequent passage than normal for an individual (4). Diarrhoea can be debilitating and potentially life-threatening, particularly when it occurs with neutropenia (5). Acute diarrhoea is particularly associated with 5-fluoruracil (5-FU) and irinotecan-based regimens as well as tyrosine kinase inhibitors (TKIs). Diarrhoea can also have a significant effect on performance status, which can lead to psychological distress, social isolation and in some cases, reluctance to continue treatment.

\subsection{Risk factors and grading}

There are numerous established risk factors for developing SACT-related diarrhoea as outlined in Table 1. The Common Terminology Criteria for Adverse Events (CTCAE) is the most frequently used system for classifying the severity of diarrhoea (Table 2) (6). While this system is important, it does not account for volume, symptom duration or patient perception regarding symptom severity (4).

\subsection{Chemotherapeutic agents frequently associated with diarrhoea}

Grade 3-4 chemotherapy-induced diarrhoea (CID) is reported in $5-47 \%$ of patients in randomised clinical trials (RCTs) (2). CID can significantly impact a patient's anti-cancer treatment, resulting in treatment alterations in approximately $60 \%$ of patients, dose delays in $28 \%$, dose reductions in $22 \%$ and complete discontinuation of treatment in $15 \%(3,7,8)$. Whilst diarrhoea can be a consequence of 
a variety of chemotherapy regimens, as shown in Table 3, it is more frequently associated with 5-FU bolus regimens and irinotecan and fluoropyrimidine combinations (9).

\subsubsection{5-fluoruracil}

Diarrhoea is a common adverse effect of $5-\mathrm{FU}$ and was reported in up to $50 \%$ of patients In the initial reports of weekly 5 -FU/leucovorin chemotherapy, with mortality rates as high as $5 \%(4,10)$. The oral 5-FU prodrug capecitabine is associated with an increased risk of grade 3-4 diarrhoea compared with 5-FU, with one meta-analysis reporting rates of $16.6 \%$ and $12.7 \%$ for capecitabine and 5-FU-based treatment respectively (11).

In some cases, genetics contribute to 5-FU toxicity. Dihydropyrimidine dehydrogenase (DPD) deficiency, caused by mutations in the gene DPYD, is associated with reduced clearance and consequent prolonged exposure to fluoropyrimidines, resulting in potentially life-threatening toxicities including severe diarrhoea, mucositis and pancytopenia (12). While complete DPD deficiency is rare, partial deficiency is present in $3-6 \%$ of cancer patients $(13,14)$. DPYD*2A is the most common polymorphism and accounts for nearly $50 \%$ of non-functional alleles (10). Pre-treatment examination for DPD deficiency, either by testing for enzyme activity or genetic variants in DPYD, is established in some centres (15) but is not in widespread use. In March 2020, the European Medicines Agency (EMA) recommended that all patients should be tested for DPD deficiency before commencing treatment with 5-FU, capecitabine and tegafur (16). Patients with complete DPD deficiency must not be treated with these agents, while in partial deficiency a reduced starting dose is advised.

\section{$\underline{2.2 .2 \text { Irinotecan }}$}

Irinotecan can cause acute diarrhoea (occurring immediately after administration) or delayed diarrhoea (occurring $>24$ hours after administration). Immediate-onset diarrhoea is caused by inhibition of acetylcholinesterase, resulting in increased cholinergic transmission within minutes of administration and patients often report symptoms of cholinergic excess, such as abdominal cramping, salivation and lacrimation (10). Average symptom duration is 30 minutes and patients typically respond rapidly to atropine [0.25-1mg subcutaneously (SC) or intravenously (IV)]. Premedication with $0.5 \mathrm{mg}$ atropine SC may prevent acute diarrhoea $(4,17)$. Late diarrhoea is common, has a median time to onset of 5 days if irinotecan is administered 3-weekly and can be life threatening, with grade $3 / 4$ events reported in $20-40 \%$ of patients $(18,19)$. 


\subsection{Targeted therapy-induced diarrhoea}

Diarrhoea is associated with the use of multiple targeted anti-cancer therapies (Supplementary Table 1), most notably TKIs, where it is one of the most common recorded toxicities, affecting up to $50 \%$ of patients (20). Severity is largely dose-dependent and can be modulated with a dose reduction(2).

\section{$\underline{2.31 \text { Pathophysiology }}$}

The exact mechanisms underlying CID remain unclear and likely involve several overlapping inflammatory, neural and secretory mechanisms. It is thought that the majority of CID occurs as a consequence of GI mucositis (21). Initiation of mucositis, believed to result from either direct or indirect cytotoxic effects of chemotherapy on rapidly dividing cells of the GI tract, triggers apoptosis. This results in epithelial atrophy and a reduction in crypt length and villus area, coupled with activation of nuclear factor-kappa B (NFKB). Subsequent up-regulation in the expression of pro-inflammatory cytokines such as interleukin-1 contributes to inflammation and ulceration along the mucosal epithelium (21). CID can then occur through three main mechanisms: secretory diarrhoea (via damage to the enterocyte transport proteins, thereby leading to an increase in the secretion of electrolytes and/or reduced absorptive capacity), osmotic diarrhoea (resulting from increased intraluminal, nonabsorbable, hypertonic substances) and altered GI motility $(2,3)$.

Much of the research into the mechanisms underlying CID has focused on irinotecan and its active metabolite SN38, believed to be $100-1000$ times more cytotoxic than irinotecan (2). SN38 is conjugated in the liver by glucuronyltransferase and deactivated to SN38-glucoronide (SN38G), a less toxic metabolite that is excreted via bile. In the stool however, SN38G may be reactivated to SN38 in the presence of $\beta$-glucuronidase, produced by the intestinal microbiome, damaging the GI mucosa as the drug is excreted $(10,22)$.

Several mechanisms underlying targeted therapy-induced diarrhoea have been proposed but the exact mechanism remains unclear for some agents. Proposed mechanisms for TKI-related diarrhoea include excess chloride secretion, inhibition of epithelial repair, and changes in gut motility and absorption amongst others (2). Less is known about the mechanisms underlying diarrhoea associated with newer targeted therapies such as poly ADP ribose polymerase (PARP) inhibitors and cyclindependent kinase (CDK) 4/6 inhibitors. 


\subsection{Assessment}

\subsubsection{Medical history}

A thorough medical history is essential in the assessment of cancer patients presenting with diarrhoea. It is important to establish baseline normal bowel function prior to the onset of diarrhoea. The frequency of bowel motions, stool consistency and the presence of blood, mucus or pus should be clarified, particularly noting whether the patient is experiencing nocturnal stools, urgency of defaecation, faecal incontinence or steatorrhoea. The presence of any of these factors requires prompt gastroenterological assessment. Questioning should also cover non-oncological causes including recent use of antibiotics, laxatives or proton pump inhibitors and any recent travel, dietary changes or contact with potentially infected individuals.

\subsubsection{Warning signs}

Table 4 lists features, which, if present along with diarrhoea, should cause clinical concern. The presence of these symptoms, the frailty status of the patient (pre-existing comorbidities, advanced age and immunocompromised) and/or a poor response to initial treatment should prompt a multidisciplinary discussion, with input from gastroenterologists, oncologists, infectious disease experts and intensivists in the most severe cases (4).

\subsubsection{Investigations}

A patient's clinical status, symptom duration and severity should guide the choice of investigations, however the majority will require routine blood tests and radiological investigations. Acid-base balance and lactate concentrations should also be measured, particularly if the patient is hypotensive or tachycardic. If a patient is febrile and neutropenic, a minimum of two sets of blood cultures are required and guidelines for febrile neutropenia should be followed (23). Patients admitted to hospital with grade 3-4 diarrhoea require urgent stool culture and Clostridium difficile testing (4). Abdominal radiography should be performed and a stool chart should be commenced. If signs of peritonism are present, abdominal CT is indicated to establish the extent of small and large bowel involvement and to exclude complications such as neutropenic enterocolitis, perforation and malignant bowel obstruction. 


\subsection{Management}

\subsubsection{General management principles}

Patients with grade 1-2 diarrhoea and no other concerning signs or symptoms are classified as uncomplicated and can usually be managed conservatively at home with oral hydration and loperamide (9). These patients should be reviewed regularly by telephone to establish symptom severity and whether face-to-face assessment is necessary (2). If diarrhoea persists for $>24$ hours despite loperamide, clinical assessment is required. Patients with grade 1-2 diarrhoea and any of the aforementioned warning signs are classified as complicated and should be hospitalised for further management as outlined below.

Those with grade 3-4 diarrhoea require urgent assessment and generally require admission (24). Intensive management of grade 3-4 diarrhoea and complicated cases typically involves fluid resuscitation, loperamide, octreotide and in some cases antibiotics (4).

\subsubsection{Acute fluid resuscitation}

Assessment of fluid balance is crucial, as patients with severe SACT-related diarrhoea can lose up to 4-6 litres of fluid per day and become profoundly hypovolaemic. In grade 3-4 diarrhoea, or when severe dehydration is present, the IV route for fluid replacement is preferred (2). If the patient is hypotensive, tachycardic and potentially septic with a high lactate concentration, an initial fluid bolus should be given (25).

It is important to note that clinicians should not stop antidiarrhoeals, even if sepsis is suspected. While infection can cause diarrhoea in patients on SACT, the probability of enteric infection appears to be low. It is crucial however that Clostridium difficile is excluded promptly. Suspected infection can be treated concurrently, as long as diarrhoea is also actively managed (2).

\subsection{Medication}

The pharmacological management of SACT-related diarrhoea, including recommend dosing, is summarised in Table 5.

\subsubsection{Opioids}


Loperamide, a high-affinity agonist against the $\mu 2$ opiate receptors, is the standard first-line therapy for SACT-related diarrhoea. While high-dose loperamide is often effective, prolonged use can lead to side effects including severe constipation and paralytic ileus, so aggressive dosing should be undertaken with close monitoring (26). If grade 1-2 diarrhoea persists for $>24$ hours despite loperamide, other opioids such as codeine can be added or used as an alternative, at the discretion of the physician.

\subsubsection{Somatostatin analogues (Octreotide)}

Octreotide, a somatostatin analogue, is the second main therapeutic option employed in the management of CID (4). Where grade 1-2 diarrhoea is high-risk or persists for $>24$ hours despite high dose loperamide and/or codeine, or in grade 3-4 diarrhoea, octreotide is usually indicated, and is typically discontinued 24 hours after symptom resolution.

\subsubsection{Uridine triacetate}

Uridine triacetate is an orally administered specific antidote to fluoropyrimidines that has been shown to improve survival and symptom resolution in cases of severe 5-FU or capecitabine toxicity or overdose (27). Uridine triacetate was licenced by the US Food and Drug Administration (FDA) and European Medicines Agency (EMA) in 2015, and in the UK in March 2020, for the management of early onset, severe and life-threatening toxicities of fluoropyrimidines including diarrhoea $(28,29)$ Guidelines recommend treatment in severe or life-threatening diarrhoea occurring within 96 hours of completion of 5-FU or capecitabine (4).

\section{Nausea and Vomiting}

While the development of increasingly effective anti-emetic regimens has reduced the incidence of chemotherapy-induced nausea and vomiting (CINV), this toxicity is one of the most feared and unpleasant side effects of SACT, with up to $40 \%$ of patients failing to achieve complete symptom control (30). Here we provide an overview of the classification and pathophysiology of CINV and current management guidelines 


\subsection{Classification}

CINV is classified into distinct syndromes according to time of onset(31-33):

- Acute CINV: occurs within minutes to hours after chemotherapy administration, with a maximal intensity after 5-6 h and resolving within $24 \mathrm{~h}$

- Delayed CINV: occurs more than 24 hours after chemotherapy administration, with peaks of intensity between 48 and 72 hours. Delayed CINV is typically more prevalent than acute CINV, which may be due to more aggressive antiemetic prophylactic strategies being implemented in the acute-phase setting (34).

- Breakthrough CINV: the continuation of symptoms within 5 days of receiving antiemetics

- Refractory CINV: nausea and/or vomiting that occurs in subsequent chemotherapy cycles despite a maximal antiemetic protocol.

- Anticipatory nausea and vomiting (ANV): precedes chemotherapy administration. This is a conditioned response, typically occurring in patients who have had a previous negative experience of vomiting associated with chemotherapy.

\subsection{Emetogenic risk}

As outlined in the National Comprehensive Cancer Network (NCCN) guidelines, four categories are used to classify the emetogenic risk of chemotherapeutic agents (the likelihood of a patient vomiting in the absence of antiemetic medications) (35):

- Highly emetogenic chemotherapy (HEC): > $90 \%$ of patients experience CINV

- Moderately emetogenic chemotherapy (MEC): $30 \%-90 \%$

- Low emetogenicity: $10 \%-30 \%$

- Minimal emetic risk: $<10 \%$

In Table 6, intravenous and oral anticancer agents are categorised according to emetogenic risk (32). Greater than $90 \%$ of patients receiving HEC will experience vomiting without prophylactic antiemetics and prophylactic measures can reduce this to $30 \%$. (35).

\subsection{Risk factors}


The incidence and severity of CINV are affected by several factors, including the therapeutic agents used, dose, route of administration and patient variables such as age, sex and prior CINV. Younger age and female gender are associated with an increased risk of CINV, while excess alcohol intake $>100 \mathrm{~g} /$ day is associated with a reduction in emesis $(35,36)$.

\subsection{Pathophysiology}

CINV involves a complex network of neuroanatomical and peripheral centres, neurotransmitters and receptors, with different mechanisms involved in acute and delayed CINV (37). Figure 1 illustrates the major regions and pathways involved. These include the chemotherapy trigger zone (CTZ) at the base of the fourth ventricle, the vomiting centre (VC) in the medulla oblongata, vagal nerve afferents projecting from GI tract to the nucleus of the solitary tract (NTS), the dorsal motor nucleus of the vagus, and the enterochromaffin cells (ECS) in the GI tract (38).

The three main neurotransmitters involved in CINV are serotonin (5-HT), which binds to the $5-\mathrm{HT}_{3}$ receptor, substance $P$ (neurokinin-1 $\left(\mathrm{NK}_{1}\right)$ receptor) and dopamine (D2 receptor) $(31,38)$. The neurotransmitters gamma aminobutyric acid (GABA), dopamine, histamine, acetylcholine and the cannabinoids are also thought to be involved, although their roles are less clear (36).

In acute CINV, free radicals generated by chemotherapeutic agents are toxic to ECs lining the GI mucosa, stimulating serotonin release (37). At elevated levels, serotonin binds to $5-\mathrm{HT}_{3}$ receptors on vagal nerve afferents (38). The central nervous system receives and processes the emetic stimuli, triggering the vomiting reflex via the NTS and CTZ (39).

Substance $P$ is the primary neurotransmitter involved in delayed CINV. Chemotherapeutic agents trigger the release of substance $\mathrm{P}$, which binds to $\mathrm{NK}_{1}$ receptors (mainly located in the NTS) to induce vomiting (37). In both acute and delayed CINV, the VC plays a crucial role in coordinating nausea and vomiting via signals from the NTS, CTZ and afferent vagal nerves (38).

\subsection{Pharmacologic therapies for CINV}

The pharmacologic classes of antiemetic agents recommended for acute and delayed CINV are shown in Table 7 and stem from differences in the underlying pathophysiology. These include $5-\mathrm{HT}_{3}$ receptor antagonists $\left(5-\mathrm{HT}_{3} \mathrm{RA}\right)$, neurokinin-1 receptor antagonists $\left(\mathrm{NK}_{1} \mathrm{RA}\right)$, corticosteroids and to a lesser extent dopamine antagonists, benzodiazepines and cannabinoids (37). Since the 1990s, CINV 
management guidelines have been issued by professional oncology organisations, including the Multinational Association of Supportive Care in Cancer/ European Society for Medical Oncology (MASCC/ESMO), the American Society of Clinical Oncology (ASCO) and the NCCN $(32,33,35,40)$. The emetogenicity of chemotherapy agents is used to direct antiemetic guidelines and a generalized scheme for antiemetic guidelines is outlined in Table 8 and Supplementary Table 2.

\section{$\underline{3.5 .15-\mathrm{HT}_{3} \text { receptor antagonists }}$}

5- $\mathrm{HT}_{3} \mathrm{RA}$ act on serotonin receptors both peripherally in the intestine and centrally in the CTZ (37). This class includes first-generation $5-\mathrm{HT}_{3} \mathrm{RA}$ (ondansetron, granisetron, dolasetron) and secondgeneration compounds (palonosetron). First-generation 5- $\mathrm{HT}_{3} \mathrm{RA}$ have a half-life of 3-9 hours, while second-generation compounds have a much longer half-life of approximately 40 hours $(37,41)$. Consequently, ondansetron, dolasetron and granisetron are most commonly used in acute CINV with palonosetron demonstrating efficacy in delayed CINV (37). Ondansetron, dolasetron and granisetron should be used with caution in patients with long QT syndrome (41).

\section{$\underline{3.5 .2 \mathrm{NK}_{1}}$ receptor antagonists}

$\mathrm{NK}_{1} \mathrm{RA}$ block the binding of substance $\mathrm{P}$ at the $\mathrm{NK}_{1}$ receptor both peripherally and centrally. Approved drugs in this class include aprepitant, fosaprepitant and rolapitant. These drugs are typically not used alone in acute CINV, but rather in combination with a $5-\mathrm{HT}_{3} \mathrm{RA}$ and dexamethasone $(32,35,40)$. Common adverse effects typically include fatigue, nausea and diarrhoea.

\subsubsection{Corticosteroids}

Despite their use in CINV since the 1980s (42), the mechanism of action of corticosteroids as an antiemetic remains unclear (37). Dexamethasone, the corticosteroid of choice for CINV, is often used in combination with other agents to increase antiemetic efficacy in both acute and delayed CINV and can be used as monotherapy in regimens with low emetogenic risk (35).

\subsubsection{Olanzapine}


Perhaps the most significant update in the management of CINV is the recommendation on the use quadruple therapy for HEC, with all guidelines now recommending the incorporation of olanzapine (10mg given once prior to administration of HEC, and then daily for 3 days) to the prophylactic antiemetic regimen of $5-\mathrm{HT}_{3} \mathrm{RA}+\mathrm{NK}_{1} \mathrm{RA}+$ dexamethasone (33). Olanzapine is an atypical antipsychotic and an antagonist at multiple receptors involved in CINV including muscarinic acetylcholine receptors, serotonin receptors, dopamine receptors and histamine receptors, and as such is a useful antiemetic agent (35). The strongest evidence for its use comes from a phase III RCT which assessed nausea prevention following the addition of olanzapine/placebo to aprepitant (or fosaprepitant) + 5- $\mathrm{HT}_{3}$ antagonist + dexamethasone in chemotherapy-naïve patients receiving $\mathrm{HEC}$ (43). When compared with placebo, significantly higher numbers of patients taking olanzapine reported no chemotherapy-induced nausea ( $74 \%$ vs. $45 \%$ at 24 hours, $P=0.002$ ) and experienced a complete response with no emesis and no use of rescue medication ( $86 \%$ vs. $65 \%$ at 24 hours, $\mathrm{P}<0.001)$. In line with this, a 2017 Cochrane review of 14 RCTs found moderate-quality evidence that olanzapine reduced CINV compared with standard management or placebo. Somnolence was a noted adverse event and caution regarding dosing was advised in the elderly (44). The latest NCCN guidelines recommend this 4-drug regimen with olanzapine, which may be substituted with levomepromazine, as a first-line option (35).

\subsubsection{Other agents}

Dopamine receptor antagonists such as metoclopramide and prochlorperazine are typically used in breakthrough CINV $(32,35,40)$. Guidelines differ regarding cannabinoids, which are recommended as alternative antiemetics in the NCCN and ASCO guidelines, but not in the MASCC/ESMO guidelines (33). A 2015 Cochrane Review reported that cannabinoids may have a role in refractory CINV but the quality of available evidence was low $(33,45)$.

\subsection{Breakthrough CINV and refractory emesis}

Antiemetics are most effective when used prophylactically and it is preferable to optimise their use in this setting (32); however, breakthrough CINV can still occur despite use of guideline-based prophylaxis. In these cases, an antiemetic with a different mode of action to the prophylactic agent(s) is recommended (32). CINV which occurs even with adequate prophylaxis necessitates a change in management (41). 


\subsection{Anticipatory nausea and vomiting}

ANV is believed to be a learned response to chemotherapy and is often more difficult to control than acute or delayed CINV (38). Risk factors for ANV include a past history of poorly controlled CINV, prior nausea and vomiting due to other causes (such as pregnancy or motion sickness), female gender, age $<50$ years and anxiety $(32,38,46)$. Pharmacological management of ANV is challenging and consequently, the optimal management strategy is effective management of acute and delayed CINV, especially at the first cycle $(32,47)$. While benzodiazepines can be used $(32)$, ANV may also respond to behavioural modification approaches such as hypnosis and music therapy (48). While behavioural therapies have proven efficacious, how best to integrate them into current practice remains unclear.

\section{Hepatotoxicity}

Drug-induced liver injury (DILI) following systemic anticancer therapy (SACT) is frequently an unpredictable and idiosyncratic reaction and is often unrelated to dose, duration or route of administration $(49,50)$. Clinical presentation ranges from an asymptomatic mild transaminitis to fulminant hepatic failure (Figure 2).

\subsection{Pathophysiology}

DILI has a range of pathophysiological manifestations, shown in Figure 2 (51-53). The most common are hepatocellular necrosis and cholestasis, accounting for an estimated $55 \%$ and $25 \%$ of DILI respectively $(54,55)$. Injury to hepatocytes occurs either due to direct hepatotoxicity with subsequent oxidative stress and apoptosis/necrosis or in the case of idiosyncratic DILI, as a result of complex interactions between a drug or its metabolites and the immune response. The role of each of these factors remains poorly understood $(56,57)$.

\section{Specific agents associated with hepatotoxicity}

\subsubsection{Chemotherapy}

The mechanism and pattern of chemotherapy-induced liver injury are in general specific to particular regimens and have been extensively reviewed $(49,58,59)$. The mechanism of injury remains poorly 
understood for some agents. 5-FU, a key component of many regimens, is associated with the development of steatosis (with an estimated prevalence of $37-47 \%),(60,61)$ oxaliplatin with sinusoidal dilatation and irinotecan with steatohepatitis $(62,63)$. Prescribing guidelines regarding specific chemotherapeutic agents are widely available but beyond the scope of this review (59).

\subsubsection{Tyrosine kinase inhibitors}

Although relatively well tolerated, many TKIs are associated with a significant increase in risk of hepatotoxicity. Hepatocellular necrosis is the most common histological manifestation and rarely progresses to cirrhosis. Estimates of grade 3 hepatotoxicity range from 1-12\% depending on the TKI used, with one meta-analysis demonstrating a four-fold increase in risk of high-grade hepatic adverse events compared with control (64). Five TKIs (pazopanib, sunitinib, regorafenib, lapatinib and ponatinib) carry a FDA 'Black Box Warning' based on reports of fatal hepatic failure (65).

\subsection{Risk factors}

A range of factors, shown in Figure 2, can predispose to SACT-related DILI (55). The presence of preexisting liver disease has relatively little impact on hepatotoxicity unless Child's Class $C$ cirrhosis is present $(66,67)$. Genetic abnormalities can affect risk; one genome-wide association study identified HLA-DQA1*02:01 as a significant risk factor for lapatinib-induced hepatotoxicity (68). Given the multiplicity of potential confounding factors, interpreting liver blood test abnormalities in the setting of SACT is challenging and a systematic diagnostic approach is required to ensure this potentially serious treatment complication is managed appropriately.

\subsection{Hepatotoxicity Classification Criteria}

Criteria for classifying derangement of routine liver blood tests include the CTCAE and DILI severity index $(6,69)$. Although the pattern of derangement can help determine the mechanism of injury, the extent of derangement is poorly reflective of the degree of liver impairment $(60,70)$ and even in cirrhosis, aspartate aminotransferase (AST) and alanine transaminase (ALT) can be normal (71).

\subsection{Assessment}


A comprehensive approach based on established British Society of Gastroenterology guidelines is required when investigating suspected DILI in a cancer patient with deranged liver blood tests (70), taking into account baseline liver function, severity of presentation, time course of liver derangement and the wider clinical picture. The comprehensive LiverTox resource provides guidelines on specific drugs, including a likelihood calculator based on frequency of reported cases (72). Further imaging, a liver screen and less commonly a liver biopsy may be indicated to exclude other causes of acute and chronic liver injury $(70,73)$. In the setting of acute liver failure (ALF), assessment should be undertaken according to established guidelines; the European Association for Study of the Liver (EASL) guidelines provide a comprehensive review in this regard (74).

\subsection{Management}

Guidelines for dose modification and discontinuation in suspected DILI vary and in practice empiric clinical judgement is often required, with the aim of instituting changes before irreversible hepatotoxicity occurs. Hy's Law forms the basis of the majority of guidelines (73) and states that DILI which leads to jaundice (without a significant cholestatic picture) leads to death or liver transplantation in $>10 \%$ of cases $(54,55,69)$. There is no definite consensus on when to discontinue anticancer therapy in presumed DILI. The generally accepted threshold below which DILI may be reversible is ALT $8 \times$ baseline; however, most protocols recommend dose alterations or discontinuation well below this, typically with a threshold of ALT $>3 \times$ upper limit of normal (ULN), (73). Where liver injury has necessitated drug discontinuation, rechallenge is rarely appropriate.

\subsubsection{Acute Liver Failure}

Cases of ALF secondary to SACT are relatively rare and $<10 \%$ of patients with non-paracetamol DILI progress to ALF; however, if they do, up to $80 \%$ die or require liver transplantation (55). The EASL guidelines provide a valuable resource regarding management of ALF (74). Careful monitoring for progression of $\mathrm{HE}$ is required, as patients can deteriorate rapidly within hours. Patients with $\geq$ grade $2 \mathrm{HE}$ or a deterioration with extrahepatic organ involvement should be transferred to critical care for appropriate airway management (74). Consideration of early referral to a specialist centre is recommended, even if unsuitable for transplant, as this is associated with improved survival.

\section{Conclusion}


Nausea and vomiting, diarrhoea and hepatotoxicity are amongst the most common SACT-related toxicities. While the establishment of evidence-based-guidelines has considerably reduced incidence, these toxicities can profoundly impact patients' quality of life and can be life-threatening.

Even with diligent adherence to current clinical guidelines, breakthrough or refractory CINV may still occur. Management of SACT-related diarrhoea must be prompt and effective, with particular caution where irinotecan-based regimens are used. Patients with grade 3-4 diarrhoea or clinical warning signs should generally be managed in the inpatient setting.

DILI secondary to SACT is often unpredictable and idiosyncratic, so liver blood tests must be carefully monitored during treatment. Guidelines aim to mitigate progression to ALF which, although rare, can be fatal.

Thorough clinical evaluation and adherence to established guidelines can significantly improve management of acute GI toxicities for patients on SACT. Ultimately, collaborative international efforts will lead to further advances in the pharmacological management as well as advancing ongoing efforts to determine biomarkers for acute GI toxicity.

\section{Practice points}

- Adherence to international practice guidelines is essential in the prevention and management of SACT-related GI toxicity.

- It is recommended that testing for DPD deficiency should be offered before commencing treatment with 5-FU or capecitabine.

- Uridine triacetate has been licenced for management of early onset, severe and lifethreatening diarrhoea secondary to fluoropyrimidines.

- Guidelines now recommend the addition of olanzapine to the prophylactic regimen of $5-\mathrm{HT}_{3}$ $\mathrm{RA}+\mathrm{NK}_{1} \mathrm{RA}+$ dexamethasone for CINV.

\section{Research agenda}

- An improved understanding of the biological and psychological predictors of acute GI toxicities of SACT is needed.

- Ongoing collaborative international translational research is required to identify those at high risk and derive new therapeutic targets to improve outcomes. 


\section{Funding}

This work was performed within the Irish Clinical Academic Training (ICAT) Programme.

This work was supported by the Wellcome Trust and the Health Research Board [Grant Number 203930/B/16/Z], the Health Service Executive National Doctors Training and Planning and the Health and Social Care, Research and Development Division, Northern Ireland.

\section{Conflict of interest statement}

Conflict of interest: None

\section{References}

1. Cancer Research UK. Cancer diagnosis and treatment statistics | Cancer Research UK [Internet]. Cancer Research UK. 2019 [cited 2020 Jul 10]. Available from: https://www.cancerresearchuk.org/health-professional/cancer-statistics/diagnosis-andtreatment\#heading-Three

2. Andreyev J, Ross P, Donnellan C, Lennan E, Leonard P, Waters C, et al. Guidance on the management of diarrhoea during cancer chemotherapy. Lancet Oncol. 2014;15(10):e447-60.

3. McQuade RM, Stojanovska V, Abalo R, Bornstein JC, Nurgali K. Chemotherapy-induced constipation and diarrhea: Pathophysiology, current and emerging treatments. Front Pharmacol. 2016;7:1-14.

4. Bossi P, Antonuzzo A, Cherny NI, Rosengarten O, Pernot S, Trippa F, et al. Diarrhoea in adult cancer patients: ESMO Clinical Practice Guidelines. Ann Oncol. 2018;29(Suppl 4):iv126-42.

5. Di Fiore F, Van Cutsem E. Acute and long-term gastrointestinal consequences of chemotherapy. Best Pract Res Clin Gastroenterol. 2009;23(1):113-24.

6. U.S. Department of Health and Human Services. Common Terminology Criteria for Adverse Events (CTCAE).v.5.0 [Internet]. 2017. Available from: https://ctep.cancer.gov/protocolDevelopment/electronic_applications/ctc.htm\#ctc_50

7. Arbuckle RB, Huber SL, Zacker C. The Consequences of Diarrhea Occurring During Chemotherapy for Colorectal Cancer: A Retrospective Study. Oncologist. 2000;5(3):250-9. 
8. Dranitsaris G, Maroun J, Shah A. Estimating the cost of illness in colorectal cancer patients who were hospitalized for severe chemotherapy-induced diarrhea. Can J Gastroenterol. $2005 ; 19(2): 83-7$.

9. Benson AB, Ajani JA, Catalano RB, Engelking C, Kornblau SM, Martenson JA, et al. Recommended guidelines for the treatment of cancer treatment-induced diarrhea. J Clin Oncol. 2004;22(14):2918-26.

10. Stein A, Voigt W, Jordan K. Review: Chemotherapy-induced diarrhea: Pathophysiology, frequency and guideline-based management. Ther Adv Med Oncol. 2010;2(1):51-63.

11. lacovelli R, Pietrantonio F, Palazzo A, Maggi C, Ricchini F, De Braud F, et al. Incidence and relative risk of grade 3 and 4 diarrhoea in patients treated with capecitabine or 5-fluorouracil: A meta-analysis of published trials. Br J Clin Pharmacol. 2014;78(6):1228-37.

12. Innocenti F, Ratain MJ, Behnke D, Raida M, Kliche KO, Pichlmeier U. Prevalence of a common point mutation in the dihydropyrimidine dehydrogenase (DPD) gene within the $5^{\prime}$-splice donor site of intron 14 in patients with severe 5-fluorouracil (5-FU)-related toxicity compared with controls. Clin Cancer Res. 2002;8(5):1314-6.

13. Lu Z, Zhang R, Carpenter JT, Diasio RB. Decreased dihydropyrimidine dehydrogenase activity in a population of patients with breast cancer: Implication for 5-fluorouracil-based chemotherapy. Clin Cancer Res. 1998;4(2):325-9.

14. Etienne MC, Lagrange JL, Dassonville O, Fleming R, Thyss A, Renée N, et al. Population study of dihydropyrimidine dehydrogenase in cancer patients. J Clin Oncol. 1994;12(11):2248-53.

15. Van Staveren MC, Jan Guchelaar H, Van Kuilenburg ABP, Gelderblom H, Maring JG. Evaluation of predictive tests for screening for dihydropyrimidine dehydrogenase deficiency. Pharmacogenomics J. 2013;13(5):389-95.

16. EU/3/09/637 | European Medicines Agency [Internet]. [cited 2020 Jun 26]. Available from: https://www.ema.europa.eu/en/medicines/human/orphan-designations/eu309637

17. Yumuk PF, Aydin SZ, Dane F, Gumus M, Ekenel M, Aliustaoglu M, et al. The absence of early diarrhea with atropine premedication during irinotecan therapy in metastatic colorectal patients [2]. Int J Colorectal Dis. 2004;19(6):609-10.

18. Bleiberg H, Cvitkovic E. Characterisation and clinical management of CPT-11 (irinotecan)induced adverse events: The European perspective. Eur J Cancer Part A. 1996;32(Suppl. 
3):S18-23.

19. Rothenberg ML, Eckardt JR, Kuhn JG, Burris HA, Nelson J, Hilsenbeck SG, et al. Phase II trial of irinotecan in patients with progressive or rapidly recurrent colorectal cancer. J Clin Oncol. 1996;14(4):1128-35.

20. Pessi MA, Zilembo N, Haspinger ER, Molino L, Di Cosimo S, Garassino M, et al. Targeted therapy-induced diarrhea: A review of the literature. Crit Rev Oncol Hematol. 2014;90(2):165-79.

21. Touchefeu Y, Montassier E, Nieman K, Gastinne T, Potel G, Bruley Des Varannes S, et al. Systematic review: The role of the gut microbiota in chemotherapy- or radiation-induced gastrointestinal mucositis - Current evidence and potential clinical applications. Aliment Pharmacol Ther. 2014;40(5):409-21.

22. Stringer AM, Gibson RJ, Logan RM, Bowen JM, Yeoh ASJ, Keefe DMK. Faecal microflora and $\beta$ glucuronidase expression are altered in an irinotecan-induced diarrhoea model in rats. Cancer Biol Ther. 2008;7(12):1919-25.

23. Klastersky J, de Naurois J, Rolston K, Rapoport B, Maschmeyer G, Aapro M, et al. Management of febrile neutropaenia: ESMO clinical practice guidelines. Ann Oncol. 2016;27(Supplement 5):v111-8.

24. Cherny NI. Evaluation and Management of Treatment-Related Diarrhea in Patients with Advanced Cancer: A Review. J Pain Symptom Manage. 2008;36(4):413-23.

25. Rivers E, Nguyen B, Havstad S, Ressler J, Muzzin A, Knoblich B, et al. Early goal-directed therapy in the treatment of severe sepsis and septic shock. N Engl J Med. 2001;345(19):136877.

26. Richardson G, Dobish R. Chemotherapy induced diarrhea. J Oncol Pharm Pract. 2007;13(4):181-98.

27. Ma WW, Saif MW, El-Rayes BF, Fakih MG, Cartwright TH, Posey JA, et al. Emergency use of uridine triacetate for the prevention and treatment of life-threatening 5 -fluorouracil and capecitabine toxicity. Cancer. 2017;123(2):345-56.

28. Saif MW. Uridine triacetate - an antidote in the treatment of 5-fluorouracil or capecitabine poisoning. Expert Opin Orphan Drugs. 2019;7(3):95-103. 
29. NHS England » Uridine triacetate for the treatment of patients exhibiting early onset severe toxicities following 5-fluorouracil or capecitabine administration (all ages) [Internet]. [cited 2020 Jun 26]. Available from: https://www.england.nhs.uk/publication/uridine-triacetate-forthe-treatment-of-patients-exhibiting-earlyonset-severe-toxicities-following-5-fluorouracil-orcapecitabine-administration-all-ages/

30. Dranitsaris G, Molassiotis A, Clemons M, Roeland E, Schwartzberg L, Dielenseger P, et al. The development of a prediction tool to identify cancer patients at high risk for chemotherapyinduced nausea and vomiting. Ann Oncol. 2017;28(6):1260-7.

31. Hesketh PJ. Chemotherapy-induced nausea and vomiting. N Engl J Med. 2008;358(23):2482.

32. Roila F, Molassiotis A, Herrstedt J, Aapro M, Gralla RJ, Bruera E, et al. 2016 MASCC and ESMO guideline update for the prevention of chemotherapy- and radiotherapy-induced nausea and vomiting and of nausea and vomiting in advanced cancer patients. Ann Oncol.

2016;27(Supplement 5):v119-33.

33. Razvi Y, Chan S, McFarlane T, McKenzie E, Zaki P, DeAngelis C, et al. ASCO, NCCN, MASCC/ESMO: a comparison of antiemetic guidelines for the treatment of chemotherapyinduced nausea and vomiting in adult patients. Support Care Cancer. 2019;27(1):87-95.

34. Grunberg SM, Deuson RR, Mavros P, Geling O, Hansen M, Cruciani G, et al. Incidence of Chemotherapy-Induced Nausea and Emesis after Modern Antiemetics: Perception versus Reality. Cancer. 2004;100(10):2261-668.

35. Berger MJ, Ettinger DS, Aston J, Barbour S, Bergsbaken J, Bierman PJ, et al. Antiemesis, version 2.2017 featured updates to the NCCN guidelines. JNCCN J Natl Compr Cancer Netw. 2017;15(7):883-93.

36. Olver I, Molassiotis A, Aapro M, Herrstedt J, Grunberg S, Morrow G. Antiemetic research: Future directions. Support Care Cancer. 2011;19(Suppl. 1):49-55.

37. Adel N. Overview of chemotherapy-induced nausea and vomiting and evidence-based therapies. Am J Manag Care. 2017;23(14):S259-65.

38. Janelsins MC, Tejani MA, Kamen C, Peoples AR, Mustian KM, Morrow GR. Current pharmacotherapy for chemotherapy-induced nausea and vomiting in cancer patients. Vol. 14, Expert Opinion on Pharmacotherapy. 2013. p. 757-66.

39. Rapoport BL. Delayed chemotherapy-induced nausea and vomiting: Pathogenesis, incidence, 
and current management. Front Pharmacol. 2017;8(JAN):1-10.

40. Hesketh PJ, Kris MG, Basch E, Bohlke K, Barbour SY, Clark-Snow RA, et al. Antiemetics: American Society of Clinical Oncology clinical practice guideline update. J Clin Oncol. 2017;35(28):3240-61.

41. Tageja N, Groninger H. Chemotherapy-induced nausea and vomiting: An overview and comparison of three consensus guidelines. Postgrad Med J. 2016;92(1083):34-40.

42. Rao K V., Faso A. Chemotherapy-induced nausea and vomiting: Optimizing prevention and management. Am Heal Drug Benefits. 2012 Jul;5(4):232-40.

43. Navari RM, Qin R, Ruddy KJ, Liu H, Powell SF, Bajaj M, et al. Olanzapine for the prevention of chemotherapy-induced nausea and vomiting. N Engl J Med. 2016;375(2):134-42.

44. Sutherland A, Naessens K, Plugge E, Ware L, Head K, Burton MJ, et al. Olanzapine for the prevention and treatment of cancer-related nausea and vomiting in adults. Cochrane Database Syst Rev. 2018;2018(9).

45. Smith LA, Azariah F, Lavender VT, Stoner NS, Bettiol S. Cannabinoids for nausea and vomiting in adults with cancer receiving chemotherapy. Cochrane Database Syst Rev. 2015;2015(11).

46. Chan A, Kim HK, Hsieh RK, Yu S, de Lima Lopes G, Su WC, et al. Incidence and predictors of anticipatory nausea and vomiting in Asia Pacific clinical practice-a longitudinal analysis. Support Care Cancer. 2015;23(1):283-91.

47. Molassiotis A, Aapro M, Dicato M, Gascon P, Novoa SA, Isambert N, et al. Evaluation of risk factors predicting chemotherapy-related nausea and vomiting: Results from a European prospective observational study. J Pain Symptom Manage. 2014;47(5):839-848.e4.

48. Dupuis LL, Robinson PD, Boodhan S, Holdsworth M, Portwine C, Gibson P, et al. Guideline for the prevention and treatment of anticipatory nausea and vomiting due to chemotherapy in pediatric cancer patients. Pediatr Blood Cancer. 2014;61(8):1506-12.

49. King PD, Perry MC. Hepatotoxicity of chemotherapeutic and oncologic agents. Gastroenterol Clin North Am. 1995;24(4):969-90.

50. Lee WM. Drug-induced hepatotoxicity. N Engl J Med. 2003;349(5):474-85.

51. Ishak KG, Zimmerman HJ. Morphologic spectrum of drug-induced hepatic disease. Gastroenterol Clin North Am. 1995;24(4):759-86. 
52. Zorzi D, Laurent A, Pawlik TM, Lauwers GY, Vauthey JN, Abdalla EK. Chemotherapy-associated hepatotoxicity and surgery for colorectal liver metastases. Br J Surg. 2007;94(3):274-86.

53. Morris-Stiff G, Tan YM, Vauthey JN. Hepatic complications following preoperative chemotherapy with oxaliplatin or irinotecan for hepatic colorectal metastases. Eur J Surg Oncol. 2008;34(6):609-14.

54. Björnsson E, Olsson R. Outcome and prognostic markers in severe drug-induced liver disease. Hepatology. 2005;42(2):481-9.

55. Andrade RJ, Lucena MI, Fernández MC, Pelaez G, Pachkoria K, García-Ruiz E, et al. DrugInduced Liver Injury: An Analysis of 461 Incidences Submitted to the Spanish Registry Over a 10-Year Period. Gastroenterology. 2005;129(2):512-21.

56. Fontana RJ. Pathogenesis of idiosyncratic drug-induced liver injury and clinical perspectives. Gastroenterology. 2014;146(4):914-928.e1.

57. Dara L, Liu ZX, Kaplowitz N. Mechanisms of adaptation and progression in idiosyncratic drug induced liver injury, clinical implications. Liver Int. 2016;36(2):158-65.

58. Floyd J, Mirza I, Sachs B, Perry MC. Hepatotoxicity of chemotherapy. Semin Oncol. 2006;33(1):50-67.

59. Grigorian A, Brien CBO. Review Article Hepatotoxicity Secondary to Chemotherapy. Journ. 2014;2:95-102.

60. Peppercorn PD, Reznek RH, Wilson P, Slevin ML, Gupta RK. Demonstration of hepatic steatosis by computerized tomography in patients receiving 5-fluorouracil-based therapy for advanced colorectal cancer. Br J Cancer. 1998;77(11):2008-11.

61. Parikh AA, Gentner B, Wu TT, Curley SA, Ellis LM, Vauthey JN. Perioperative complications in patients undergoing major liver resection with or without neoadjuvant chemotherapy. J Gastrointest Surg. 2003;7(8):1082-8.

62. Vauthey JN, Pawlik TM, Ribero D, Wu TT, Zorzi D, Hoff PM, et al. Chemotherapy regimen predicts steatohepatitis and an increase in 90-day mortality after surgery for hepatic colorectal metastases. J Clin Oncol. 2006;24(13):2065-72.

63. Fernandez FG, Ritter J, Goodwin JW, Linehan DC, Hawkins WG, Strasberg SM. Effect of steatohepatitis associated with irinotecan or oxaliplatin pretreatment on resectability of 
hepatic colorectal metastases. J Am Coll Surg. 2005;200(6):845-53.

64. Teo YL, Ho HK, Chan A. Risk of tyrosine kinase inhibitors-induced hepatotoxicity in cancer patients: A meta-analysis. Cancer Treat Rev. 2013;39(2):199-206.

65. US Food and Drug Administration (FDA). Drugs@FDA: FDA-Approved Drugs [Internet]. Silver Spring (MD): FDA (US). 2018 [cited 2020 Jun 23]. Available from:

https://www.accessdata.fda.gov/scripts/cder/daf/

66. Huet PM, Villeneuve JP, Fenyves D. Drug elimination in chronic liver diseases. J Hepatol Suppl. 1997;26(2):63-72.

67. Schenker S, Martin RR, Hoyumpa AM. Antecedent liver disease and drug toxicity. J Hepatol. 1999;31(6):1098-105.

68. Spraggs $C F$, Budde LR, Briley LP, Bing N, Cox CJ, King KS, et al. HLA-DQA ${ }^{*} 02: 01$ is a major risk factor for lapatinib-induced hepatotoxicity in women with advanced breast cancer. J Clin Oncol. 2011;29(6):667-73.

69. Chalasani N, Bonkovsky HL, Fontana R, Lee W, Stolz A, Talwalkar J, et al. Features and outcomes of 899 patients with drug-induced liver injury: The DILIN prospective study. Gastroenterology. 2015;148(7):1340-1352.e7.

70. Newsome PN, Cramb R, Davison SM, DIllon JF, Foulerton M, Godfrey EM, et al. Guidelines on the management of abnormal liver blood tests. Gut. 2018;67(1):6-19.

71. Johnston DE. Special considerations in interpreting liver function tests. Am Fam Physician. 1999;59(8):2223-30.

72. LiverTox: Clinical and Research Information on Drug-Induced Liver Injury [Internet] - PubMed [Internet]. [cited 2020 Jul 13]. Available from: https://pubmed.ncbi.nlm.nih.gov/31643176/

73. US FDA. Drug-Induced Liver Injury : Premarketing Clinical Evaluation. FDA Guidelines 2009.

74. European Association for the Study of the Liver. EASL Clinical Practical Guidelines on the management of acute (fulminant) liver failure. J Hepatol. 2017;66(5):1047-81.

75. Clinical N, Guidelines P, Guidelines N. Antiemesis. 2020.

76. Aapro M, Gralla RJ, Roila F, Herrstedt J, Molassiootis A. MASCC / ESMO Antiemetic Guideline 2016 with Updates in 2019. Vol. 1, Multinational Association of Supportive Care in Cancer. 
2016. p. 1-21. 


\section{Table 1}

Risk factors for developing chemotherapy-induced diarrhoea

\begin{tabular}{|c|c|}
\hline Patient factors & Therapy-related factors \\
\hline $\begin{array}{ll}\text { - } & \text { Older age } \\
\text { - } & \text { Poor performance status } \\
\text { - } & \text { Female gender } \\
\text { - } & \text { Presence of tumour in the bowel } \\
\text { - } & \text { Associated bowel pathology such as lactose } \\
& \text { intolerance }\end{array}$ & $\begin{array}{l}\text { - } \\
\text { Agent specific (for example capecitabine/ 5- } \\
\text { - Infusional chemotherapy } \\
\text { - Weekly chemotherapy scheduling } \\
\text { - Concomitant abdominal-pelvic radiation } \\
\text { - } \text { and chemotherapy } \\
\text { Prior history of chemotherapy-induced } \\
\text { diarrhoea }\end{array}$ \\
\hline
\end{tabular}




\section{Table 2}

National Cancer Institute (NCI) CTCAE grading of diarrhoea v5.0.

\begin{tabular}{|l|l|l|l|l|}
\hline Grade 1 & Grade 2 & Grade 3 & Grade 4 & Grade 5 \\
\hline Increase of <4 & Increase of 4-6 & Increase of $\geq 7$ & Life-threatening & Death \\
stools per day over & stools per day over & stools per day over & consequences; & \\
baseline; mild & baseline; moderate & baseline; & urgent intervention & \\
increase in stoma & increase in stoma & hospitalisation & indicated & \\
output compared & output compared & indicated; severe & & \\
to baseline & to baseline; & increase in stoma & & \\
& limiting & output compared & & \\
& instrumental ADL & to baseline; limiting & & \\
& & self-care ADL & & \\
& & & & \\
& & & & \\
\hline
\end{tabular}

$A D L$, activities of daily living. 


\section{Table 3}

Rates of CTCAE grade 3-4 diarrhoea for frequently used chemotherapeutic agents and combinations.

\begin{tabular}{|l|l|}
\hline Chemotherapy & Incidence of grade 3-4 diarrhoea (\%) \\
\hline Single agent therapy: & 32 (Grade 3) \\
5-FU (bolus) & $6-13$ \\
5-FU (continuous Infusion) & $16-22$ \\
Irinotecan (late diarrhoea) & 11 \\
Capecitabine & 4 \\
Docetaxel/paclitaxel & \\
Combination therapy: & 47 \\
CapelRI & 20 \\
FOLFOXIRI & 19 \\
mIFL & 16 \\
Bolus fluorouracil with folinic acid & 15 \\
Irinotecan with fluorouracil and folinic acid & 14 \\
Docetaxel with capecitabine & 14 \\
FOLFIRI & 10 \\
FLOX &
\end{tabular}

5-FU, 5-Fluorouracil; CapeIRI capecitabine/irinotecan; FLOX, bolus fluorouracil/leucovorin/oxaliplatin; FOLFIRI, fluorouracil/leucovorin/irinotecan; FOLFOXIRI, fluorouracil/leucovorin/oxaliplatin/irinotecan; mIFL, irinotecan/bolus fluorouracil.

Adapted from $(4,10)$. 


\section{Table 4}

Clinical warning signs indicating a potentially complicated clinical course

\begin{tabular}{|l|}
\hline Warning signs \\
\hline Febrile neutropenia, neutropenic sepsis \\
Fever \\
Shock \\
Renal impairment \\
Electrolyte imbalance \\
Inability to eat \\
Nausea, vomiting and dehydration with reduced urine output \\
Increasing fatigue \\
Previous admission for diarrhoea \\
Abdominal cramps not relieved by loperamide \\
Peritonitis \\
Blood loss \\
Delirium
\end{tabular}

Adapted from (4) 
Table 5

Overview of medications used in the treatment of SACT-related diarrhoea

\begin{tabular}{|c|c|c|c|c|c|}
\hline Medication & Indication & Mode of action & Dosing & Administration & Caution \\
\hline Loperamide & $\begin{array}{l}\text { First-line treatment of } \\
\text { diarrhoea }\end{array}$ & $\begin{array}{l}\text { Synthetic opiate with direct } \\
\text { effects on gastrointestinal } \\
\text { smooth muscle }\end{array}$ & $\begin{array}{l}4 \mathrm{mg} \text { initial dose followed } \\
\text { by } 2 \mathrm{mg} \text { every } 2-4 \text { hours } \\
\text { thereafter (or after every } \\
\text { loose stool) up to a } \\
\text { maximum of } 16 \mathrm{mg} \text { per } \\
\text { day* }\end{array}$ & Oral & $\begin{array}{l}\text { Minimal absorption and } \\
\text { systemic effects; aggressive } \\
\text { dosing risks paralytic ileus }\end{array}$ \\
\hline Codeine & Alternative to loperamide & $\begin{array}{l}\text { Opioid that works via central } \\
\text { and local mechanisms to delay } \\
\text { transit time through small and } \\
\text { large intestines }\end{array}$ & $\begin{array}{l}\text { 15-60mg up to four times } \\
\text { per day (maximum dose } \\
240 \mathrm{mg} \text { in } 24 \text { hours) }\end{array}$ & Oral & Nausea, sedation \\
\hline Octreotide & $\begin{array}{l}\text { Grade 3-4 diarrhoea, } \\
\text { persistent or high-risk } \\
\text { grade 1-2 diarrhoea }\end{array}$ & $\begin{array}{l}\text { Somatostatin analogue, causes } \\
\text { suppression of hormones (e.g. } \\
\text { vasoactive intestinal peptide) } \\
\text { and gastric acid secretion, } \\
\text { reduction in gastrointestinal } \\
\text { motility, reduced pancreatic } \\
\text { secretions and promotion of } \\
\text { intestinal absorption }\end{array}$ & $\begin{array}{l}100-150 \mu \mathrm{g} \\
\text { subcutaneously three } \\
\text { times daily, dose can be } \\
\text { titrated up to } 500 \mu \mathrm{g} \\
\text { subcutaneously three } \\
\text { times daily }\end{array}$ & $\begin{array}{l}\text { Subcutaneous } \\
\text { injection or infusion } \\
\text { (preferred) or } \\
\text { intravenous } \\
\text { injection or infusion } \\
(25-50 \mu \mathrm{g} / \mathrm{h})\end{array}$ & $\begin{array}{l}\text { Can precipitate steatorrhoea, } \\
\text { may reduce insulin } \\
\text { requirements in type } 1 \\
\text { diabetes }\end{array}$ \\
\hline Uridine triacetate & $\begin{array}{l}\text { Early onset, severe and } \\
\text { life-threatening toxicities }\end{array}$ & $\begin{array}{l}\text { Prodrug of uridine, lipophilic } \\
\text { and quickly absorbed by the gut, }\end{array}$ & $\begin{array}{l}10 \mathrm{~g} \text { orally every } 6 \text { hours } \\
\text { for } 20 \text { doses }\end{array}$ & Oral & Nausea, vomiting, diarrhoea \\
\hline
\end{tabular}




\begin{tabular}{|c|c|c|c|c|c|}
\hline & $\begin{array}{l}\text { of fluoropyrimidines, or } \\
\text { overdose }\end{array}$ & $\begin{array}{l}\text { delivering high concentrations } \\
\text { of uridine which competes with } \\
\text { toxic 5-FU metabolites }\end{array}$ & & & \\
\hline Budesonide & $\begin{array}{l}\text { Second-line for persistent } \\
\text { grade 1-2 uncomplicated } \\
\text { diarrhoea refractory to } \\
\text { loperamide }\end{array}$ & $\begin{array}{l}\text { Topically active corticosteroid, } \\
\text { high activity in inflammatory } \\
\text { bowel disease, } 90 \% \text { first-pass } \\
\text { effect in liver and therefore low } \\
\text { bioavailability }\end{array}$ & $\begin{array}{l}\text { 9mg once daily for 3-5 } \\
\text { days }\end{array}$ & Oral & $\begin{array}{l}\text { Increased risk of infection; } \\
\text { systemic effects of steroids are } \\
\text { possible }\end{array}$ \\
\hline Atropine & $\begin{array}{l}\text { Acute onset diarrhoea } \\
\text { starting }<24 \text { hours after } \\
\text { irinotecan administration }\end{array}$ & $\begin{array}{l}\text { Competitive inhibition of } \\
\text { acetylcholine at muscarinic } \\
\text { receptors }\end{array}$ & $\begin{array}{l}0.25 \mathrm{mg} \text { for prophylaxis/ } \\
\text { treatment of cholinergic } \\
\text { effects of irinotecan }\end{array}$ & $\begin{array}{l}\text { Subcutaneous or } \\
\text { intravenous } \\
\text { injection }\end{array}$ & $\begin{array}{l}\text { Caution required in elderly } \\
\text { patients; contraindicated in } \\
\text { glaucoma }\end{array}$ \\
\hline Antibiotics & $\begin{array}{l}\text { Grade 3-4 diarrhoea } \\
\text { associated with } \\
\text { neutropenia, fever and } \\
\text { hypotension }\end{array}$ & $\begin{array}{l}\text { Broad spectrum antibiotics } \\
\text { targeting anaerobic organisms } \\
\text { and small intestinal bacterial } \\
\text { overgrowth }\end{array}$ & $\begin{array}{l}\text { Regimen-dependant, } \\
\text { choice should be based } \\
\text { upon resistance patterns } \\
\text { and allergy status }\end{array}$ & Oral or intravenous & $\begin{array}{l}\text { Increased risk of Clostridium } \\
\text { difficile colitis }\end{array}$ \\
\hline
\end{tabular}

* A more aggressive regimen ( $4 \mathrm{mg}$ initially, then $2 \mathrm{mg}$ every two hours or $4 \mathrm{mg}$ every four hours until diarrhoea free for 12 hours) is recommended for severe diarrhoea and that related to use of high-dose irinotecan or irinotecan plus bolus FU and leucovorin.

Adapted from (2) 


\section{Table 6}

Emetogenic potential of intravenous and oral chemotherapeutic agents and targeted therapies in solid tumours.

\begin{tabular}{|c|c|c|}
\hline Emetogenic risk & Intravenous agents & Oral agents* \\
\hline HEC (>90\%) & $\begin{array}{l}\text { Anthracycline/ cyclophosphamide (AC) } \\
\text { combination } \\
\text { Carmustine } \\
\text { Cisplatin } \\
\text { Cyclophosphamide } \geq 1500 \mathrm{mg} / \mathrm{m}^{2} \\
\text { Dacarbazine } \\
\text { Mechlorethamine } \\
\text { Streptozocin }\end{array}$ & $\begin{array}{l}\text { Hexamethylmelamine } \\
\text { Procarbazine }\end{array}$ \\
\hline MEC (30\%-90\%) & $\begin{array}{l}\text { Carboplatin } \\
\text { Cyclophosphamide }<1500 \mathrm{mg} / \mathrm{m}^{2} \\
\text { Daunorubicin } \\
\text { Doxorubicin } \\
\text { Epirubicin } \\
\text { Idarubicin } \\
\text { Ifosfamide } \\
\text { Irinotecan } \\
\text { Oxaliplatin } \\
\text { Temozolamide } \\
\text { Thiotepa } \\
\text { Trabectedin }\end{array}$ & $\begin{array}{l}\text { Ceritinib } \\
\text { Crizotinib } \\
\text { Cyclophosphamide } \\
\text { Imatinib } \\
\text { Temozolomide } \\
\text { Vinorelbine }\end{array}$ \\
\hline Low (10\%-30\%) & $\begin{array}{l}\text { Aflibercept } \\
\text { Belinostsat } \\
\text { Cabazitaxel } \\
\text { Cetuximab } \\
\text { Docetaxel } \\
\text { Eribulin } \\
\text { Etoposide } \\
\text { 5-flurouracil } \\
\text { Gemcitabine } \\
\text { Methotrexate }\end{array}$ & $\begin{array}{l}\text { Afatinib } \\
\text { Axitinib } \\
\text { Capecitabine } \\
\text { Dabrafenib } \\
\text { Everolimus } \\
\text { Etoposide } \\
\text { Lapatinib } \\
\text { Olaparib } \\
\text { Pazopanib } \\
\text { Regorafenib }\end{array}$ \\
\hline
\end{tabular}




\begin{tabular}{|c|c|c|}
\hline & $\begin{array}{l}\text { Mitoxantrone } \\
\text { Mitomycin } \\
\text { Nab-paclitaxel } \\
\text { Paclitaxel } \\
\text { Panitumumab } \\
\text { Pegylated liposomal doxorubicin } \\
\text { Pemetrexed } \\
\text { Pertuzumab } \\
\text { Temsirolimus } \\
\text { Topotecan } \\
\text { Trastuzumab-emtansine } \\
\text { Vinflunine }\end{array}$ & $\begin{array}{l}\text { Sunitinib } \\
\text { Tegafur uracil } \\
\text { Vandetanib }\end{array}$ \\
\hline Minimal (<10\%) & $\begin{array}{l}\text { Bevacizumab } \\
\text { Bleomycin } \\
\text { Fulvestrant } \\
\text { Goserelin } \\
\text { Trastuzumab } \\
\text { Vincristine } \\
\text { Vinblastine } \\
\text { Vinorelbine }\end{array}$ & $\begin{array}{l}\text { Erlotinib } \\
\text { Gefitinib } \\
\text { Hydroxyurea } \\
\text { Melphalan } \\
\text { Methotrexate } \\
\text { L-phenylalanine mustard } \\
\text { Sorafenib } \\
\text { Vemurafenib } \\
\text { Vismodegib }\end{array}$ \\
\hline
\end{tabular}

*Emetic potential of oral agents is classified upon a full course of therapy rather than a single dose

Adapted from (32). 
Table 7

Antiemetic agents according to pharmacologic class

\begin{tabular}{|c|c|}
\hline Pharmacologic class & Agents \\
\hline $5-\mathrm{HT}_{3} \mathrm{RA}$ & $\begin{array}{l}\text { - } \text { Granisetron } \\
\text { - Ondansetron } \\
\text { - Palonosetron }\end{array}$ \\
\hline $\mathrm{NK}_{1} \mathrm{RA}$ & $\begin{array}{ll}\text { - } & \text { Aprepitant } \\
\text { - } & \text { Fosaprepitant } \\
\text { - } & \text { Rolapitant }\end{array}$ \\
\hline $\mathrm{NK}_{1} \mathrm{RA} / 5-\mathrm{HT}_{3} \mathrm{RA}$ combination & - Netupitant/palonosetron hydrochloride \\
\hline Corticosteroid & - Dexamethasone \\
\hline Atypical antipsychotic & - Olanzapine \\
\hline Dopamine antagonists & $\begin{array}{l}\text { - Metoclopramide } \\
\text { - Prochlorperazine }\end{array}$ \\
\hline Benzodiazepines & $\begin{array}{ll}\text { - } & \text { Alprazolam } \\
\text { - } & \text { Lorazepam }\end{array}$ \\
\hline Cannabinoids & $\begin{array}{ll}\text { - } & \text { Dronabinol } \\
\text { - } & \text { Nabilone }\end{array}$ \\
\hline
\end{tabular}

5-HT ${ }_{3}$ RA, 5-hydroxytryptamine3 receptor antagonist; $\mathrm{NK}_{1} \mathrm{RA}$, neurokinin-1 receptor antagonist

Adapted from (37) 
Table 8

Generalized antiemetic guidelines

\begin{tabular}{|c|c|}
\hline Chemotherapy emetic risk & Recommended antiemetics \\
\hline \multicolumn{2}{|l|}{ Acute CINV } \\
\hline High Emetogenic Capacity & $\begin{array}{l}\text { - } \mathrm{NK}_{1} \mathrm{RA}+5-\mathrm{HT}_{3} \mathrm{RA}+\mathrm{DEX} \\
\text { - } \mathrm{NK} \mathrm{K}_{1} \mathrm{RA} / 5-\mathrm{HT}_{3} \mathrm{RA} \text { combination + DEX } \\
\text { - } \mathrm{Olanzapine}+\text { palonosetron + DEX } \\
\text { - } \mathrm{NK}{ }_{1} \mathrm{RA}+5-\mathrm{HT}_{3} \mathrm{RA}+\mathrm{DEX}+\text { olanzapine }\end{array}$ \\
\hline Moderate Emetogenic Capacity & $\begin{array}{ll}\text { - } & 5-\mathrm{HT}_{3} \mathrm{RA}+\mathrm{DEX} \\
\text { - } & \mathrm{NK}_{1} \mathrm{RA}+5-\mathrm{HT}_{3} \mathrm{RA}+\mathrm{DEX} \\
\text { - } & \mathrm{NK}_{1} \mathrm{RA} / 5-\mathrm{HT}_{3} \mathrm{RA} \text { combination + DEX } \\
\text { - } & \text { Olanzapine + palonosetron + DEX }\end{array}$ \\
\hline Low Emetogenic Capacity & - DEX or DRA or $5-\mathrm{HT}_{3} \mathrm{RA}$ \\
\hline Minimal Emetogenic Capacity & - $\quad$ No routine prophylaxis \\
\hline \multicolumn{2}{|l|}{ Delayed CINV } \\
\hline High Emetogenic Capacity & $\begin{array}{ll}\text { - } & \mathrm{NK}_{1} \mathrm{RA}+\mathrm{DEX} \\
\text { - } & \mathrm{DEX} \\
\text { - } & \text { Olanzapine } \\
\text { - } & \mathrm{NK}_{1} \mathrm{RA}+\mathrm{DEX}+\text { olanzapine }\end{array}$ \\
\hline Moderate Emetogenic Capacity & $\begin{array}{ll}\text { - } & \mathrm{DEX} \\
\text { - } & 5-\mathrm{HT}_{3} \mathrm{RA} \text { monotherapy } \\
\text { - } & \mathrm{NK} \mathrm{K}_{1} \mathrm{RA}+/-\mathrm{DEX} \\
\text { - } & \mathrm{DEX} \\
\text { - } & \text { Olanzapine }\end{array}$ \\
\hline Low Emetogenic Capacity & - DEX or DRA or $5-\mathrm{HT}_{3} \mathrm{RA}$ \\
\hline Minimal Emetogenic Capacity & - $\quad$ No routine prophylaxis \\
\hline Breakthrough/ refractory & $\begin{array}{l}\text { Add one agent from a different drug class to current } \\
\text { regimen, such as: } \\
\text { - Olanzapine } \\
\text { - Benzodiazepine } \\
\text { - Cannabinoid }\end{array}$ \\
\hline
\end{tabular}




\begin{tabular}{|c|c|}
\hline & $\begin{array}{ll}\text { - } & \mathrm{DRA} \\
\text { - } & 5-\mathrm{HT}_{3} \mathrm{RA} \\
\text { - } & \mathrm{DEX}\end{array}$ \\
\hline Anticipatory & $\begin{array}{l}\text { - } \text { Prevention first } \\
\text { - } \text { Behavioural therapy } \\
\text { - } \text { Acupuncture/ acupressure } \\
\text { - Benzodiazepine }\end{array}$ \\
\hline
\end{tabular}

5-HT 3 RA, 5-hydroxytryptamine3 receptor antagonist, DRA, dopamine receptor antagonist; DEX, dexamethasone; NK 1 RA, neurokinin-1 receptor antagonist.

${ }^{a}$ Order of regimens/agents does not indicate preference

${ }^{b}$ Specific dosing recommendations can be found in antiemetic guidelines $(32,35,40)$

Adapted from (37). 
Figure 1: Major centres and pathways involved in chemotherapy-induced nausea and vomiting (CINV).

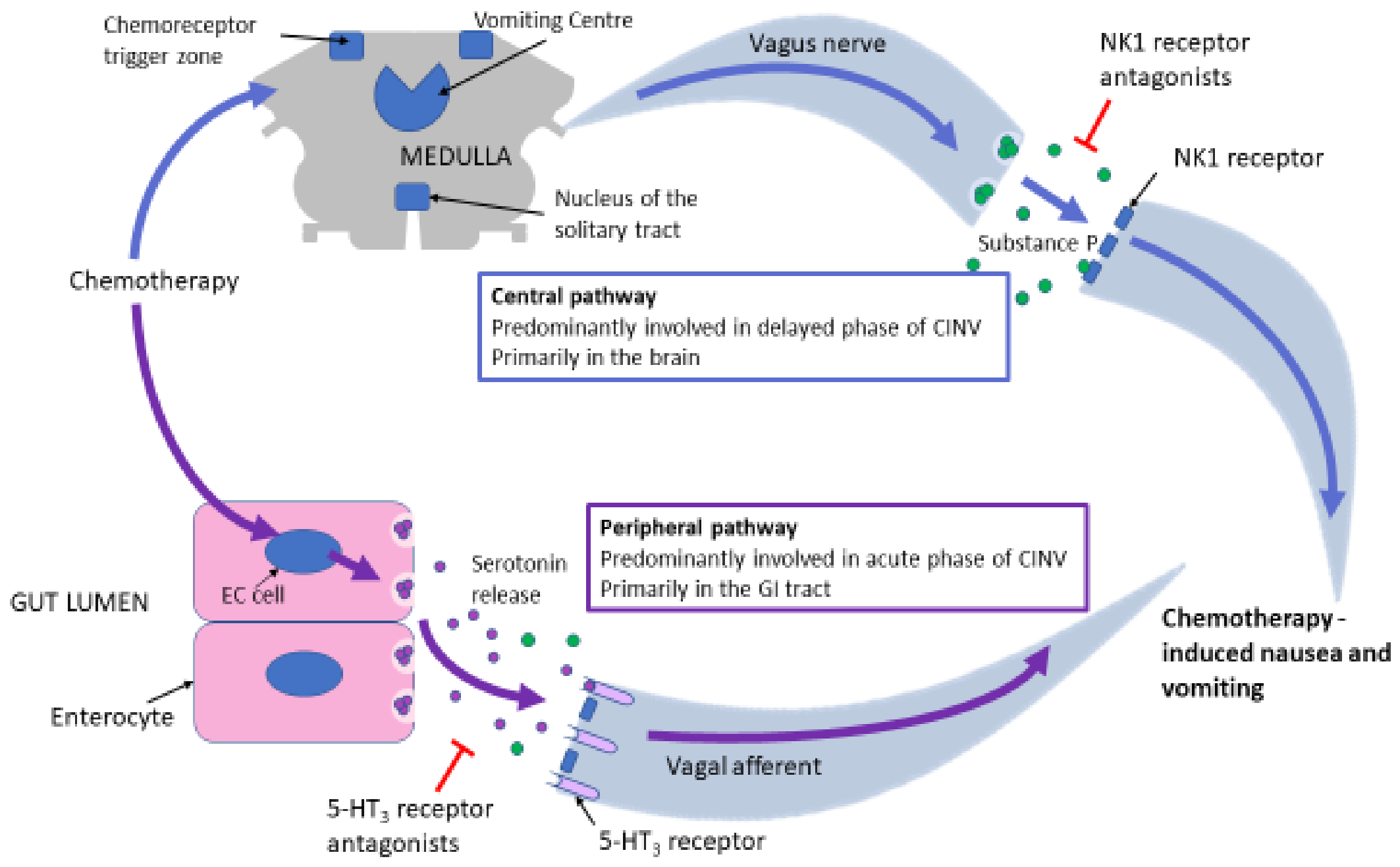


Figure 2: Major centres and pathways involved in chemotherapy-induced nausea and vomiting (CINV). The central pathway primarily involves the brain and the peripheral pathway primarily involves the $\mathrm{Gl}$ tract.

$\mathrm{EC}$, enterochromaffin cell; $\mathrm{NK}_{1}$, neurokinin 1.

Adapted from (31). 
Figure 2: Hepatotoxicity secondary to SACT: Predisposing factors, clinical presentation and histopathological findings.

\section{Hepatotoxicity and systemic anticancer therapy}
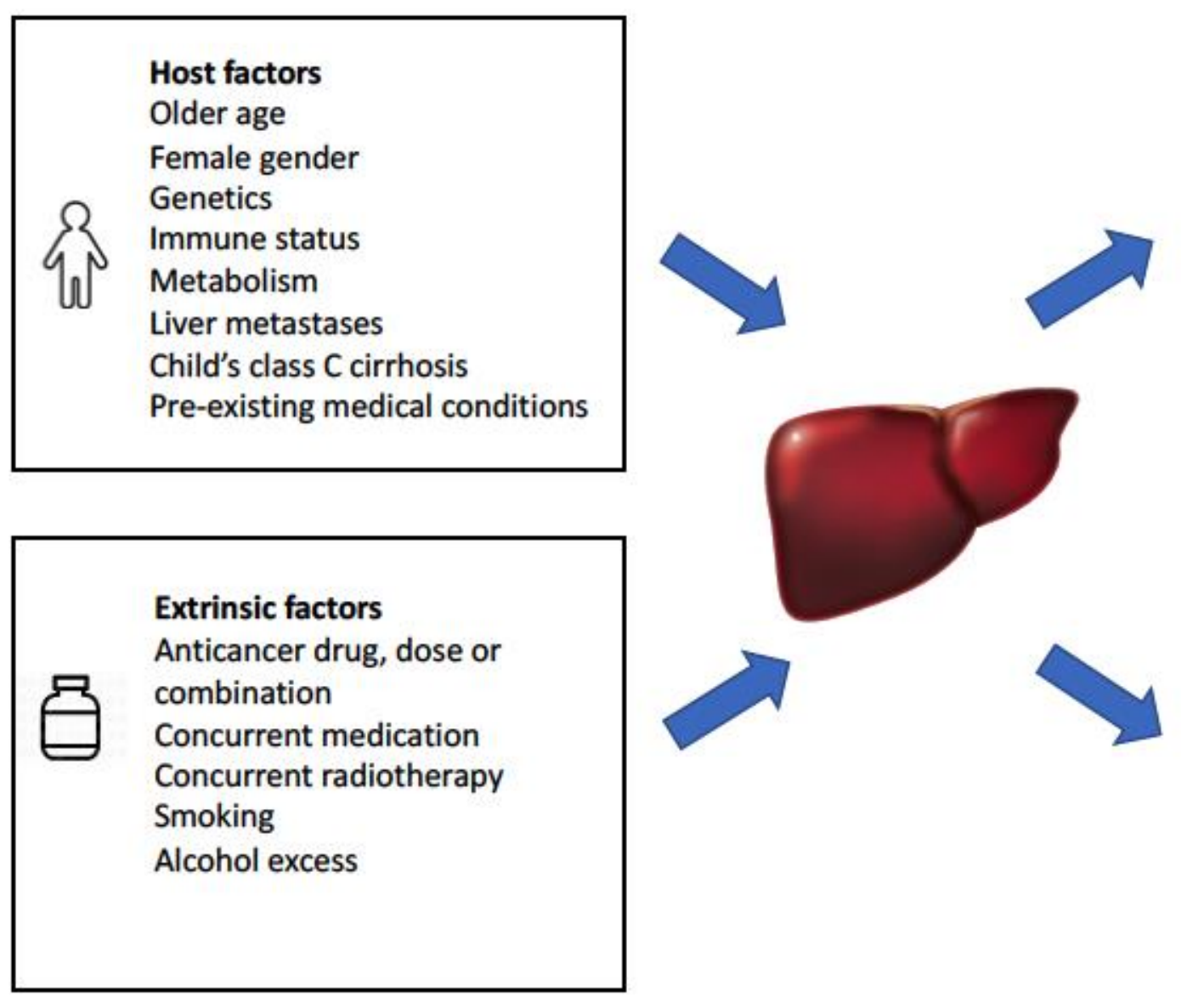

Range of clinical presentation

Asymptomatic

Deranged liver blood tests

Cholestatic / Hepatitis

Fibrosis and cirrhosis

Malignant transformation

Veno-occlusive disease

Sinusoidal obstruction

Hepatic failure

\section{Pattern of injury}

Hepatocellular necrosis

Cholestasis

Steatosis

Veno-occlusion

Peliosis hepatitis

Ductal injury fibrosis 
Supplementary Table 1: Incidence of diarrhoea from targeted therapies

\begin{tabular}{|c|c|c|c|}
\hline Class of drug & Drug & $\begin{array}{l}\text { Incidence of } \\
\text { diarrhoea (\%) }\end{array}$ & $\begin{array}{l}\text { Incidence of grade } 3 \\
\text { and } 4 \text { diarrhoea (\%) }\end{array}$ \\
\hline Anti-EGFR & $\begin{array}{l}\text { Afatinib } \\
\text { Cetuximab } \\
\text { Erlotinib } \\
\text { Gefitinib } \\
\text { Panitumumab }\end{array}$ & $\begin{array}{l}87-95 \\
13-28 \\
18-57 \\
26-52 \\
21\end{array}$ & $\begin{array}{l}14-22 \\
4-28 \\
3-6 \\
1-5 \\
8-20\end{array}$ \\
\hline Anti-HER2 & $\begin{array}{l}\text { Lapatinib } \\
\text { Pertuzumab } \\
\text { Trastuzumab }\end{array}$ & $\begin{array}{l}47-75 \\
67 \\
2-63\end{array}$ & $\begin{array}{l}3-14 \\
5-8 \\
2-6\end{array}$ \\
\hline Anti-BRAF & Dabrafenib & 1 & 0 \\
\hline Anti-MEK & $\begin{array}{l}\text { Cobimetinib } \\
\text { Trametinib }\end{array}$ & $\begin{array}{l}45-50 \\
45-50\end{array}$ & $\begin{array}{l}4 \\
4\end{array}$ \\
\hline Anti-VEGF & Bevacizumab & 20 & $2-7$ \\
\hline Multi-targeted TKI & $\begin{array}{l}\text { Imatinib } \\
\text { Lenvantinib } \\
\text { Pazopanib } \\
\text { Regorafenib } \\
\text { Sorafenib } \\
\text { Sunitinib }\end{array}$ & $\begin{array}{l}20-26 \\
58 \\
52 \\
34-40 \\
43-55 \\
44-55\end{array}$ & $\begin{array}{l}1 \\
8 \\
4 \\
5-8 \\
2-8 \\
5-8\end{array}$ \\
\hline Anti-mTOR & $\begin{array}{l}\text { Everolimus } \\
\text { Temsirolimus }\end{array}$ & $\begin{array}{l}30 \\
27\end{array}$ & $\begin{array}{l}1-3 \\
1\end{array}$ \\
\hline Anti-CKD/6 & $\begin{array}{l}\text { Palbociclib } \\
\text { Ribociclib }\end{array}$ & $\begin{array}{l}21-26 \\
35\end{array}$ & $\begin{array}{l}1-4 \\
1.2\end{array}$ \\
\hline PARP inhibitor & $\begin{array}{l}\text { Olaparib } \\
\text { Rucaparib }\end{array}$ & $\begin{array}{l}11-18 \\
13-20\end{array}$ & $\begin{array}{l}0 \\
0\end{array}$ \\
\hline
\end{tabular}


CKD, cyclin-dependent kinase; EGFR, epidermal growth factor receptor; HER2, human epidermal growth factor receptor 2; MEK, MAPK ERK kinase; mTOR, mammalian target of rapamycin; PARP, poly(adenosine diphosphateribose) polymerase; TKI, tyrosine kinase inhibitor, VEGF, vascular endothelial growth factor.

Adapted from (4). 


\section{Supplementary Table 2A}

CINV prophylaxis recommendations for HEC regimens

\begin{tabular}{|c|c|c|c|}
\hline HEC regimen type & ASCO & NCCN & MASCC/ ESMO \\
\hline $\begin{array}{l}\text { Non-AC, cisplatin, } \\
\text { and others } \\
\text { (Acute) }\end{array}$ & $\begin{array}{l}\text { 4-drug antiemetic regimen: } \\
\mathrm{NK}_{1} \mathrm{RA}+5-\mathrm{HT} 3 \mathrm{RA}+\text { dexamethasone } \\
\text { + olanzapine }\end{array}$ & $\begin{array}{l}3 \text { different drug regimens offered: } \\
\text { A) NK} K_{1} R A+5-H T 3 \text { RA + dexamethasone + olanzapine } \\
\text { B) Palonosetron + dexamethasone + olanzapine } \\
\text { C) NK } 1 \text { RA + 5-HT3 RA + dexamethasone }\end{array}$ & $\begin{array}{l}\text { 3-drug antiemetic regimen: } \\
\mathrm{NK}_{1} \mathrm{RA}+5-\mathrm{HT} 3 \mathrm{RA}+\text { dexamethasone +/- } \\
\text { olanzapine* }\end{array}$ \\
\hline $\begin{array}{l}\text { AC } \\
\text { (Acute) }\end{array}$ & $\begin{array}{l}\text { 4-drug antiemetic regimen: } \\
\mathrm{NK}_{1} \mathrm{RA}+5-\mathrm{HT} 3 \mathrm{RA}+\text { dexamethasone } \\
\text { + olanzapine }\end{array}$ & $\begin{array}{l}3 \text { different drug regimens offered: } \\
\text { A) NK} K_{1} \mathrm{RA}+5-\mathrm{HT} 3 \mathrm{RA}+\text { dexamethasone + olanzapine } \\
\text { B) Palonosetron + dexamethasone + olanzapine } \\
\text { C) NK}{ }_{1} \mathrm{RA}+5-\mathrm{HT}_{3} \mathrm{RA}+\text { dexamethasone }\end{array}$ & $\begin{array}{l}\text { 3-drug antiemetic regimen: } \\
\mathrm{NK}_{1} \mathrm{RA}+5-\mathrm{HT} 3 \mathrm{RA}+\text { dexamethasone +/- } \\
\text { olanzapine* }\end{array}$ \\
\hline $\begin{array}{l}\text { Non-AC, cisplatin, } \\
\text { and others } \\
\text { (Delayed) }\end{array}$ & $\begin{array}{l}\text { 2-drug antiemetic regimen: } \\
\text { Dexamethasone + olanzapine }\end{array}$ & 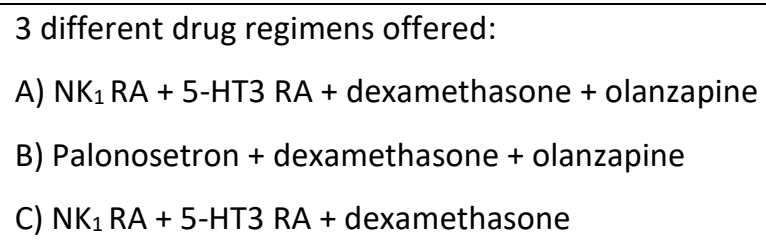 & $\begin{array}{l}\text { Dexamethasone, or if aprepitant used in acute; } \\
\text { metoclopramide + dexamethasone, or: } \\
\text { NK}_{1} \text { RA (aprepitant) + dexamethasone, } \\
\text { all +/- olanzapine }\end{array}$ \\
\hline $\begin{array}{l}\text { AC } \\
\text { (Delayed) }\end{array}$ & Olanzapine & 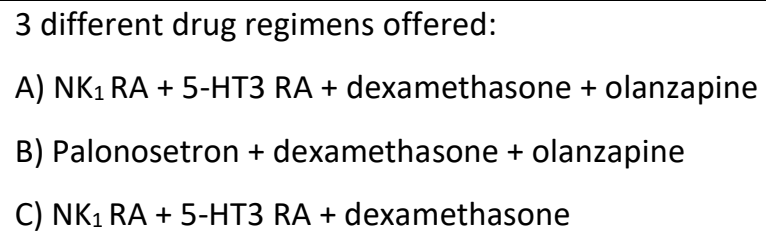 & $\begin{array}{l}\text { No prophylaxis, or if aprepitant used in acute; } \\
\text { Dexamethasone +/- olanzapine, or; } \\
\text { NK }_{1} \text { RA (aprepitant) +/- olanzapine }\end{array}$ \\
\hline
\end{tabular}

* Olanzapine may be added particularly if nausea is a concern.

5-HT3 RA, 5-hydroxytryptamine3 receptor antagonist; AC, anthracycline-cyclophosphamide combination; ASCO, American Society of Clinical Oncology; CINV, chemotherapyinduced nausea and vomiting; ESMO, European Society of Medical Oncology; HEC, highly emetogenic chemotherapy; NK ${ }_{1}$ RA, neurokinin-1 receptor antagonist; MASCC, Multinational Association of Supportive Care in Cancer; NCCN, National Comprehensive Cancer Network. 
Adapted from $(33,75,76)$ 


\section{Table Supplementary Table 2B}

CINV prophylaxis recommendations for MEC regimens

\begin{tabular}{|c|c|c|c|}
\hline MEC regimen type & ASCO & NCCN & MASCC/ ESMO \\
\hline $\begin{array}{l}\text { Non-carboplatin } \\
\text { (Acute) }\end{array}$ & $\begin{array}{l}\text { 2-drug antiemetic regimen: } \\
\text { 5-HT3 RA + dexamethasone }\end{array}$ & $\begin{array}{l}3 \text { different drug regimens offered: } \\
\text { D) 5-HT3 RA + dexamethasone } \\
\text { E) Palonosetron + dexamethasone + olanzapine } \\
\text { F) NK }{ }_{1} \mathrm{RA}+5-\mathrm{HT} 3 \mathrm{RA}+\text { dexamethasone }\end{array}$ & $\begin{array}{l}\text { 2-drug antiemetic regimen: } \\
\text { 5-HT3 RA + dexamethasone }\end{array}$ \\
\hline $\begin{array}{l}\text { Carboplatin AUC } \geq 4 \\
(\mathrm{mg} / \mathrm{mL}) / \mathrm{min} \\
\text { (Acute) }\end{array}$ & $\begin{array}{l}\text { 3-drug antiemetic regimen: } \\
\mathrm{NK}_{1} \mathrm{RA}+5-\mathrm{HT}_{3} \mathrm{RA}+\text { dexamethasone }\end{array}$ & $\begin{array}{l}3 \text { different drug regimens offered: } \\
\text { D) 5-HT3 RA + dexamethasone } \\
\text { E) Palonosetron + dexamethasone + olanzapine } \\
\text { F) NK } 1 \text { RA + 5-HT3 RA + dexamethasone }\end{array}$ & $\begin{array}{l}\text { 3-drug antiemetic regimen: } \\
\mathrm{NK}_{1} \mathrm{RA}+5-\mathrm{HT} 3 \mathrm{RA}+\text { dexamethasone }\end{array}$ \\
\hline $\begin{array}{l}\text { Non-carboplatin } \\
\text { (Delayed) }\end{array}$ & $\begin{array}{l}\text { No prophylaxis, or: } \\
\text { dexamethasone for MEC agents known to } \\
\text { cause delayed CINV }\end{array}$ & $\begin{array}{l}3 \text { different drug regimens offered: } \\
\text { D) } 5-H T 3 \text { RA + dexamethasone } \\
\text { E) Palonosetron + dexamethasone + olanzapine } \\
\text { F) NK } 1 \text { RA + 5-HT3 RA + dexamethasone }\end{array}$ & $\begin{array}{l}\text { No prophylaxis, or: } \\
\text { dexamethasone for MEC agents known } \\
\text { to cause delayed CINV }\end{array}$ \\
\hline $\begin{array}{l}\text { Carboplatin AUC } \geq 4 \\
(\mathrm{mg} / \mathrm{mL}) / \mathrm{min} \\
\text { (Delayed) }\end{array}$ & No prophylaxis & $\begin{array}{l}3 \text { different drug regimens offered: } \\
\text { D) 5-HT3 RA + dexamethasone } \\
\text { E) Palonosetron + dexamethasone + olanzapine } \\
\text { F) NK } 1 \text { RA + 5-HT3 RA + dexamethasone }\end{array}$ & $\begin{array}{l}\text { No prophylaxis, or: } \mathrm{NK}_{1} \mathrm{RA} \text { (if used in } \\
\text { acute) }\end{array}$ \\
\hline
\end{tabular}

5-HT3 RA, 5-hydroxytryptamine3 receptor antagonist; ASCO, American Society of Clinical Oncology; AUC, area under the curve; CINV, chemotherapy-induced nausea and vomiting; ESMO, European Society of Medical Oncology; MEC, moderately emetogenic chemotherapy; NK ${ }_{1}$ RA, neurokinin-1 receptor antagonist; MASCC, Multinational Association of Supportive Care in Cancer; NCCN, National Comprehensive Cancer Network.

Adapted from $(33,75,76)$ 


\section{Supplementary Table 2C}

CINV prophylaxis recommendations for low and minimal emetic chemotherapy regimens

\begin{tabular}{|l|l|l|l|}
\hline Low/ minimal emetic regimen type & ASCO & NCCN & MASCC/ ESMO \\
\hline $\begin{array}{l}\text { Low emetogenic risk regimen (all) } \\
\text { (Acute) }\end{array}$ & 5-HT3 RA or dexamethasone & $\begin{array}{l}\text { One of: dexamethasone, metoclopramide, } \\
\text { prochlorperazine or 5-HT3 RA }\end{array}$ & $\begin{array}{l}\text { One of: 5-HT3 RA, dopamine receptor } \\
\text { antagonist or dexamethasone }\end{array}$ \\
\hline $\begin{array}{l}\text { Low emetogenic risk regimen (all) } \\
\text { (Delayed) }\end{array}$ & No prophylaxis & No prophylaxis & No prophylaxis \\
\hline $\begin{array}{l}\text { Minimal emetogenic risk regimen (all) } \\
\text { (Acute) }\end{array}$ & No prophylaxis & No prophylaxis & No prophylaxis \\
\hline $\begin{array}{l}\text { Minimal emetogenic risk regimen (all) } \\
\text { (Delayed) }\end{array}$ & No prophylaxis & No prophylaxis & No prophylaxis \\
\hline
\end{tabular}

5-HT3 RA, 5-hydroxytryptamine3 receptor antagonists; ASCO, American Society of Clinical Oncology; CINV, chemotherapy-induced nausea and vomiting; ESMO, European Society of Medical Oncology; MASCC, Multinational Association of Supportive Care in Cancer; NCCN, National Comprehensive Cancer Network.

Adapted from $(33,75,76)$ 